\title{
PENGARUH KINERJA KEUANGAN TERHADAP RETURN SAHAM OTOMOTIF DAN KOMPONEN LAINNYA PADA BEI
}

\author{
Adminah \\ Muh. Faisal \\ Program studi S1 Manajemen, Fakultas Ekonomi dan Bisnis, Universitas Tadulako \\ Email: aamia678@gmail.com; muh58faisal@gmail.com
}

\begin{abstract}
This study aims to determine the effect of financial performance partially or simultaneously on stock returns in the automotive sector and other components on the Indonesia Stock Exchange. This study measured financial performance variables using liquidity ratios measured by Current Ratio $(C R)$, solvency (DER), activity (TATO) and profitability (ROE). The analytical method used in this research is multiple linear regression analysis. The results showed simultaneously liquidity $(C R)$, solvency (DER), activity (TATO) and profitability (ROE) had no significant effect on stock returns on automotive companies and other components on the IDX. Partially liquidity (CR) does not significantly influence stock returns, solvency (DER) does not significantly influence stock returns, activity (TATO) does not significantly influence stock returns and profitability (ROE) does not significantly influence stock returns.
\end{abstract}

Keywords: Current Ratio, Debt to Equity Ratio, Total Assets Turnover Return On Equity.

\begin{abstract}
ABSTRAK
Penelitian ini bertujuan untuk mengetahui pengaruh kinerja keuangan secara parsial maupun simultan terhadap return saham pada sektor otomotif dan komponen lainnya pada Bursa Efek Indonesia. Penelitian ini variabel kinerja keuangan diukur dengan menggunakan rasio likuiditas diukur dengan Current Ratio (CR), solvabilitas (DER), aktivitas (TATO) dan profitabilitas (ROE). Metode analisis yang digunakan dalam penelitian adalah analisis regresi linear berganda. Hasil penelitian menunjukan secara simultan likuiditas (CR), solvabilitas (DER), aktivitas (TATO) dan profitabilitas (ROE) tidak berpengaruh secara signifikan terhadap return saham pada perusahaan otomotif dan komponen lainnya pada BEI. Secara parsial likuiditas (CR) tidak berpengaruh secara signifikan terhadap return saham, solvabilitas (DER) tidak berpengaruh secara signifikan terhadap return saham, aktivitas (TATO) tidak berpengaruh secara signifikan terhadap return saham dan profitabilitas (ROE) tidak berpengaruh secara signifikan terhadap return saham.
\end{abstract}

Kata Kunci: Current Ratio, Debt to Equity Ratio, Total Assets TurnOver Return On Equity.

\section{PENDAHULUAN}

Perkembangan perekonomian yang didukung oleh peningkatan komunikasi akan meningkatkan pula upaya berbagai perusahaan dalam mengembangkan usahanya dan melakukan kegiatan untuk meraih ekspansi bisnis dengan berbagai cara agar menarik perhatian investor dan memberikan keuntungan yang lebih. Perusahaan otomotif merupakan salah satu kategori sektor industri di Bursa Efek Indonesia (BEI) yang mempunyai peluang untuk tumbuh dan berkembang. Hal ini karena banyak perusahaan mobil yang terkenal di dunia membuka pabrik manufaktur mobil meningkatkan kapasitas produksinya di indonesia, negara dengan ekonomi terbesar di Asia Tenggara. Menurut Harjito dan Martono (2012:383) Pasar modal (capital market) adalah suatu pasar dimana dana-dana jangka panjang baik hutang maupun modal sendiri diperdagangkan. Dana jangka panjang yang diperdagangkan tersebut diwujudkan dalam bentuk surat-surat berharga. Jenis surat berharga yang diperjual belikan di pasar modal memeliki jatuh tempo lebih dari satu tahun dan ada yang tidak memiliki jatuh tempo. 
Fluktuasi return saham yang terjadi pada perusahaan otomotif juga disebabkan karena pada umumnya masih dominan dipengaruhi oleh kondisi keuangannya. Kondisi ini akan mempengaruhi keputusan investor untuk membeli saham perusahaan tersebut dan menjual saham yang telah dimiliki untuk menghindari risiko kerugian. alat yang digunakan untuk mengukur kinerja keuangan perusahaan adalah dengan menggunakan rasio-rasio yaitu rasio likuiditas, rasio aktivitas, rasio solvabilitas dan aktivitas. Rasio likuiditas yaitu rasio yang menunjukan hubungan antara kas perusahaan dan aktiva lancar lainnya dan hutang lancar. Rasio ini digunakan untuk mengukur kemampun perusahaan dalam memenuhi kewajiban jangka pendeknya. Rasio aktivitas yaitu rasio yang mengukur efiiensi perusahaan dalam menggunakan aset-asetnya. Rasio solvabilitas yaitu rasio yang mengukur seberapa banyak perusahaan mengunakan dana dari hutang. Rasio profitabilitas yaitu rasio yang menunjukan kemampuan perusahaan untuk memperoleh keuntungan dari penggunaan modalnya.

Industri manufaktur sektor otomotif yang terdaftar di bursa efek indonesia yang menjadi sampel dalam penelitian ini dimana penggunaan aktiva, modal dan hutang dapat berpengaruh terhadap return saham dilihat dari perbandingan kinerja keuangn setiap tahunnya seperti pada perusahaan Laba bersih PT. Astra International Tbk dari tahun ke tahun mengalami fluktuasi. Pada tahun 2012-2013 laba bersih mengalami penurunan akan tetapi return yang diperoleh mengkat hal ini karena hutang pada perusahaan tersebut lebih besar dibandingkan modal sendiri. Tahun 2013-2016 laba bersih mengalami peningkatan hal ini karena semakin besar laba yang diperoleh perusahaan maka akan berdampak bagi perusahaan dan minat investor untuk berinvestasi yang mengakibatkan semakin besar pula nilai return saham. perusahaan PT. Selamat Sempurna Tbk laba bersihnya mengalami kenaikan, akan tetapi return saham mengalami fluktuasi, hal ini karena harga saham pada perusahaan tersebut mengalami fluktuasi sehingga reurn saham juga mengalami fluktuasi.

Berdasarkan data-data tersebut memberikan gambaran ketidak konsistenan antara perkembangan aktiva, hutang, modal dan laba bersih sebagai perhitungan return saham. Perkembangan aktiva, hutang, modal dan laba bersih terkadang diikuti oleh peningakatan return saham terkadang juga diikuti oleh penurunan return saham pada perusahaan otomotif yang diteliti. Uraian tersebut berkaitan dengan pengambilan keputusan kinerja keuangan yang akan dipakai suatu perusahaan untuk menghasilkan return saham yang diperoleh. Perusahaan otomotif harus meningkatkan return saham agar bisa bersaing dengan perusahaan lain yang terdaftar di Bursa Efek Indonesia.

\section{KAJIAN LITERATUR DAN KERANGKA PEMIKIRAN}

Menurut Darsono (2007:47) Kinerja keuangan merupakan hasil kegiatan operasi perusahaan yang disajikan dalam bentuk angka-angka keuangan. Hasil kegiatan perusahaan periode sekarang harus dibandingakan dengan kinerja keuangan masa lalu, anggaran neraca dan laba rugi dan rata-rata kinerja keuangan perusahaan sejenis. Saham adalah tanda bukti penyertaan kepemilikan modal pada suatu perusahaan atau kertas yang tercantum dengan jelas nilai nominal, nama perusahaan dan diikuti dengan hak dan kewajiban yang dijelaskan kepada setiap pemegangangnya (Fahmi 2016:271)

Fahmi (2016:358), Return adalah keuntungan yang diperoleh oleh perusahaan, individu dan institusi dari hasil kebijakan investasi yang dilakukannya jadi, return saham adalah hasil dari keuntungan atau kerugian dari suatu investasi saham. Menurut Fahmi (2016:65) Terdapat beberapa macam jenis rasio keuangan dapat digunakan untuk menilai kinerja suatu perusahaan yaitu likuiditas, solvabilitas, aktivitas dan profitabilitas.

Pada penelitian ini kinerja keuangan dihitung dengan menggunakan Rasio likuiditas yang paling umum digunakan adalah Current Ratio Current Ratio rendah menunjukan terjadinya masalah atau ketidak mampuan perusahaan memenuhi kewajiban jangka pendeknya. Current Ratio yang tinggi disebabkan adanya kelebihan kas, piutang yang tak tertagih atau persediaan yang tidak terjual, yang tentu saja tidak sempat dipakai untuk membayar hutang atau aktiva lancar lainnya dibandingkan dengan yang dibutuhkan sekarang atau tingkat likuidas rendah dari pada aktiva lancar dan sebalikanya pendapat ini didukung oleh penelitian yang dilakukan Syeh (2016) yang menemukan bahwa CR berpengaruh positif signifikan terhadap return saham. 
Menurut Kasmir (2010:112) rasio solvabilitas adalah diukur dengan Debt to Equity Ratio (DER), berguna untuk mengetahui jumlah dana yang disediakan peminjam (kreditor) dengan pemilik perusahaan, rasio ini digunakan untuk mengetahui setiap rupiah modal sendiri yang dijadikan untuk jaminan utang. DER juga merupakan hutang jangka panjang, semakain tinggi DER menunjukan tingkat pengembalian yang diterima investor berupa dividen semakin kecil maka yang ditanggung investor semakin tinggi sehingga, resiko perusahaan akan semakin besar dalam memenuhi utangnya, yaitu harus membayar utang pokok dengan bunga. Hal ini menjukan dampak menurunya harga saham suatu perusahaan dan return saham akan menurun.

Menurut Fahmi (2016:80) Total Asset Turn Over atau perputaran total asset Rasio ini digunakan untuk mengukur sejauh mana keseluruhan aset yang dimiliki oleh perusahaan terjadi perputaran secara efektif. Apabila rasio rendah itu merupakan indikasi bahwa tidak berpotensi pada volume yang menandai bagi kapasitas investasinya, semakin tinggi nilai TATO maka semakin efisiensi perusahaan dalam menggunakan seluruh asetnya dan penjualan perusahaan akan meningkat.

Fahmi (2016:82) Rasio Profitabilitas adalah mengukur efektivitas manajemen secara keseluruhan yng ditunjukan besar kecilnya tingkat keuntungan yang diperoleh dalam hubungannya dengan penjualan maupun investasi. Semakin baik rasio profitabilitas maka semakain baik kemampuan keuntngan yang diperoleh perusahaan. Rasio Profitabilitas dapat diukur dengan menggunakan Retrun On Equity. semakin tinggi nilai ROE maka menunjukan kinerja perusahaan yang semakin baik karena tingkat pengembalian investasi (return) yang semakin besar.

Return saham adalah keuntungan yang diperoleh perusahaan, individu dari hasil kebijakan investasi yang dilakukannya (Fahmi 2016:358). Semakin tinggi return saham perusahaan maka semakin likuit suatu perusahaan dan akan menarik invertor untuk menanamkan modal pada perusahaan tersebut.

\section{METODE PENELITIAN}

Jenis penelitian ini yaitu deskriptif dengan pendekatan kuantitatif. Penelitian ini dilakukan dengan melihat laporan keuangan perusahaan otomotif yang terdaftar di Bursa Efek Indonesia tahun 20122017. Data penelitian ini yaitu data sekunder yang diambil dari laporan keuangan otomotif yang diperoleh dari situs Bursa Efek Indonesia (BEI) yaitu www.idx.co.id dan www.sahamok.com.

Teknik pengumpulan data yang digunakan penelitian ini yaitu menggunakan dokumentasi. Populasi pada penelitian ini yaitu industri manufaktur sektor otomotif dan komponen lainnya pada Bursa Efek Indonesia yaitu 12 perusahaan. Teknik pengambilan sampel yang digunakan yaitu purposive sampling, yaitu penentuan sampel menggunakan kriteria tertentu (sugiyono 2015:156).

\section{Uji Normalitas}

Menurut kurniawan (2014:156) Uji normalitas ini bertujuan untuk menguji apakah uji regresi variabel dependen dan independen mempunyai distribusi normal atau tidak. Penelitian ini menggunakan taraf signifikan sebesar 0,05 atau $5 \%$ jadi, jika nilai signifikan $>0,05$ maka data tersebut normal. Namun jika nilai signifikan $\leq 0,05$ maka data tersebut tidak berdistribusi normal. Uji normalitas juga dapat dilihat dengan melihat tabel histogram dan penyebaran data (titik) sumber dari grafik normal probability plot, jika titik-titik menyebar disekitar garis diagonal maka data tersebut berdistribusi normal.

\section{Uji Multikolenieritas}

Menurut Kurniawan (2014:157) Uji Multikoloniaritas digunakan untuk mengetahui ada atau tidaknya penyimpangan asumsi klasik. Peluang terjadinya multikolenieritas akan semakin besar sejalan dengan bertambahnya jumlah variabel independen model regresi yang baik seharusnya tidak terjadi kolerasi diantara variabel independen, jika variabel independen saling berkorelasi, maka variabel-variabel ini tidak ortogonal. Variabel ortogonal adalah variabel independen yang nilai 
korelasi antar sesama variabel independen sama dengan nol. Multikolenieritas dapat dilihat dengan menggunakan atau melihat uji yang disebut Variance Inflation Factor (VIP) nilai VIP kurang dari 10 meunjukan tidak terdapat gejala multikolenieritas, artinya tidak terdapat hubungan antar variabel independen.

\section{Uji Autokorelasi}

Menurut Kurniawan (2014:158), Uji autokorelasi bertujuan menguji apakah model linear ada korelasi antara kesalahan pada periode t dengan kesalahan periode t-1 (sebelumnya). Apabila terjadi hal tersebut maka menunjukan masalah pada uji autokorelasi. Persamaan regresi yang baik adalah yang tidak memiliki masalah autokorelasi. Uji atutokorelasi bertujuan untuk megetahui apakah dalam model regresi linear ada korelasi antara kesalahan penggangu pada periode dengan kesalahan penggangu pada periode sebelumnya (Ghozali, 2016:107). Model regresi yang baik adalah model yang bebas dari autokorelasi. Untuk mendeteksi ada dan tidaknya autokorelasi digunakan run test. Run test merupakan bagian dari statistik non prametrik yang digunakan untuk menguji apakah antara residual terdapat korelasi yang tinggi atau tidak, jika antara residual tidak terdapat korelasi maka dikatakan bahwa residual adalah acak atau random.

\section{Uji Heterokestatisitas}

Menurut Kurniawan (2014:158) Uji heterokesdatisitas digunakan untuk mengetahui ada atau tidaknya penyimpangan asumsi klasik heterokesdatisitas yaitu adanya ketidak varian dari residual pada semua pengamatan dalam model regresi. Dasar analisis sebagai berikut:

1) Jika ada pola tertentu, seperti titik yang membentuk pola tertentu yang teratur (bergelombang, melebar kemudian menyempit), maka terjadi heterokesdatisitas

2) Jika tidak ada pola yang jelas, serta titik-titik yang menyebar diatas dan dibawah angka nol pada sumbu Y, maka tidak terjadi heterokesdatisitas.

\section{Analisis Regresi Linear Berganda}

Penelitian ini menggunakan data kuantitatif dengan pengujian statistik yaitu regresi linear berganda dan pengujian hipotesis. Analisis regresi linear berganda bertujuan untuk mengetahui pengaruh kinerja keuangan terhadap return saham sektor otomotif yang terdaftar di BEI. Menurut Sugiyono (2014:227) rumus regresi linear berganda dapat di dijabarkan sebagai berikut:

$$
\mathbf{Y}=\alpha+b_{1} X_{1}+b_{2} X_{2}+b_{3} X_{3}+b_{n} X_{n}+e
$$

Persamaan Regresi Linear Berganda diatas diaplikasikan pada penelitian ini adalah:

$$
\mathbf{Y}=a+b_{1}(C R)+b_{2}(D E R)+b_{3}(T A T O)+b_{4}(R O A)+e
$$

\section{Uji Simultan (uji F)}

Uji F digunakan untuk menguji tingkat pengaruh variabel independen terhadap variabel dependen secara bersama-sama. Langkah-langkah pengujian hipotesis menggunakan uji statistik $\mathrm{F}$ sebagai berikut:

1) Jika f-hitung > F-tabel pada tingkat kepercayaan $95 \%(\alpha=0.05)$ maka terbukti current ratio $(\mathrm{CR})$, Debt to Equity Ratio (DER), Retrun On Asset (ROA) dan Total Asset Turn Over (TATO) secara simultan berpengaruh signifikan terhadap Retun saham. Hal ini menunjukan Ho ditolak dan Ha diterima.

2) Jika f-hitung < F-tabel pada tingkat kepercayaan 95\% $(\alpha=0.05)$ maka terbukti current ratio $(\mathrm{CR})$, Debt to Equity Ratio (DER), Retrun On Asset (ROA) dan Total Asset Turn Over (TATO) secara simultan tidak berpengaruh signifikan terhadap Retun saham. Hal ini menunjukan Ho diterima dan Ha ditolak 
Vol. 6, No.2, Mei 2020, 149-157

\section{Uji Parsial (Uji t)}

Uji t digunakan untuk menguji signifikansi pengaruh masing-masing variabel independen secara parsial terhadap variabel dependen. Langkah-langkah pengujian hipotesis menggunakan uji t sebagai berikut:

1) Jika $t_{\text {hitung }}>t_{\text {tabel }}$ pada tingkat kepercayaan $95 \%(\alpha=0.05)$ maka terbukti current ratio (CR), Debt to Equity Ratio (DER), Retrun On Asset (ROA) dan Total Asset Turn Over (TATO) secara parsial berpengaruh signifikan terhadap Return saham. Hal ini menunjukan Ho ditolak dan Ha diterima.

2) Jika $\mathrm{T}_{\text {hitung }}<\mathrm{T}_{\text {tabel }}$ pada tingkat kepercayaan 95\% $(\alpha=0.05)$ maka terbukti Current Ratio $(\mathrm{CR})$, Debt to Equity Ratio (DER), Return On Asset (ROA) dan Total Asset Turn Over (TATO) secara parsial tidak berpengaruh signifikan terhadap Return saham. Hal ini menunjukan Ho diterima dan Ha ditolak.

\section{HASIL DAN PEMBAHASAN}

Hasil Analisis Regresi Linear Berganda

\begin{tabular}{|c|c|c|c|c|c|c|c|c|}
\hline \multicolumn{9}{|c|}{ Coefficients $^{a}$} \\
\hline \multirow{2}{*}{\multicolumn{2}{|c|}{ Model }} & \multicolumn{2}{|c|}{ Unstandardized Coefficients } & $\begin{array}{l}\text { Standardized } \\
\text { Coefficients }\end{array}$ & \multirow[b]{2}{*}{$\mathrm{T}$} & \multirow[b]{2}{*}{ Sig. } & \multicolumn{2}{|c|}{ Collinearity Statistics } \\
\hline & & B & Std. Error & Beta & & & Tolerance & VIF \\
\hline 1 & (Constant) & -28.751 & 582.955 & & -.049 & .961 & & \\
\hline & CR & -.552 & 1.774 & -.054 & -.311 & .758 & .872 & 1.147 \\
\hline & DER & -783.874 & 502.821 & -.302 & -1.559 & .129 & .697 & 1.436 \\
\hline & TATO & -602.279 & 763.295 & -.224 & -.789 & .436 & .325 & 3.074 \\
\hline & ROE & 44.506 & 34.543 & .359 & 1.288 & .207 & .337 & 2.972 \\
\hline
\end{tabular}

a. Dependent Variable: RETURN SAHAM

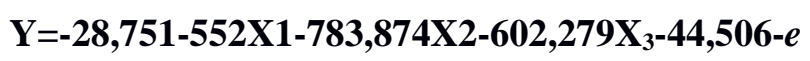

Nilai konstanta sebesar -28,751 bertanda negatif ini menunjukan bahwa jika Current Ratio (X1), Debt to Equity Ratio(X2), Total Assets Turnover (X3), Return On Equity (X4) sama dengan nol maka Return saham (Y) akan sebesar -28,751 satuan. Nilai koefisien Current Ratio (X1) sebesar -552 bertanda negatif hal ini menunjukan bahwa jika Current Ratio meningkat satu kesatuan maka akan menurunkan return saham (Y) sebesar -552 satuan dengan asumsi variabel bebas Debt to Equity Ratio (X2), Total Assets Turn Over (X3), Return On Equity (X4) konstan. Nilai koefisien Debt to Equity Ratio (X2) sebesar $-703,874$ bertanda negatif hal ini menunjukan bahwa jika Debt to Equity Ratio meningkat satu kesatuan maka akan menurunkan Return saham (Y) sebesar -703,874 satuan dengan asumsi variabel bebas Current Ratio (X1), Total Assets Turnover (X3), Return On Equity (X4) konstan. Nilai koefisien Total Assets Turn Over (X3) sebesar -602,279 bertanda negatif hal ini menunjukan bahwa jika Total Assets Turn Over meningkat satu kesatuan maka akan menurunkan Return saham (Y) sebesar -602,279 satuan dengan asumsi variabel bebas Current Ratio, Debt to Equity Ratio (X2), Return On Equity (X4) konstan. 


\section{Uji Hipotesis}

\section{Uji Simultan (Uji F)}

Hasil analisis ini diperoleh nilai uji similtan $\mathrm{F}_{\text {hitung }} 1,815<\mathrm{F}_{\text {tabel }} 2,67$ dan tingkat signifikansi 0,151.nilai signifikansi tersebut jauh lebih besar dari 0,05 maka dapat disimpukan bahwa secara simultan Current Ratio (CR), Debt to Equity Rqtio (DER), Total Assetss TurnOver (TOTO) dan Return On Equity (ROE) tidak berpengaruh signifikan terhadap Return saham. Hal ini berarti Ho diterima dan H1 ditolak.

\section{Uji Parsial (Uji t)}

Current ratio (X1) dengan nilai $\mathrm{t}_{\text {hitung }}$ sebesar hitung $(-0.311)<\mathrm{t}_{\text {tabel }}(2,75)$ dengan taraf signifikansi $0,758>0,05$. Dari hasil tersebut dapat disimpukan bahwa Current Ratio tidak berpengaruh signifikan terhadap return saham. Hal ini berarti Ho diterima dan H1 ditolak. (2) Debt to Equity Ratio (X2) Debt to Equity Ratio memiliki nilai $\mathrm{t}_{\text {hitung }}(-1,559)<\mathrm{t}_{\text {tabel }}(2,75)$ dengan taraf signifikansi $0.129>0,05$. Dari hasil tersebut dapat disimpulkan bahwa Debt to Equity Ratio tidak berpengaruh signifikan terhadap Return saham. Hal ini Ho diterima dan H1 ditolak. (3) Total Assets Turn Over (X3) Total Assets Turn Over memiliki nilai $\mathrm{t}_{\text {hitung }}(-0,789)<\mathrm{t}_{\text {tabel }}(2,75)$ dengan taraf signifikansi $0.436>0,05$. Dari hasil tersebut dapat disimpulkan bahwa Total Assets Turn Over tidak berpengaruh signifikan terhadap Return saham. Hal ini Ho diterima dan H1 ditolak. (4) Return On Equity (X4) variabel Return On Equity memiliki nilai $\mathrm{t}_{\text {hitung }}(1,288)<\mathrm{t}_{\text {tabel }}(2,75)$ dengan taraf signifikansi $0.337>0,05$. Dari hasil tersebut dapat disimpulkan bahwa Return On Equity tidak berpengaruh signifikan terhadap return saham. Hal ini Ho diterima dan H1 ditolak.

\section{PEMBAHASAN}

Hasil pengujian hipotesis pertama menunjukan bahwa Current Ratio (CR), Debt to Equity Ratio (DER), Total Assets Turn Over (TATO), Return On Equity (ROE) Terhadap Return Saham secara simultan tidak berpengaruh signifikan terhadap return saham. Berdasarkan uji $\mathrm{F}$ dapat diketahui bahwa secara simultan variabel independen Current Ratio (CR), Debt to Equity Ratio (DER), Total Assets TurnOver (TATO), Return On Equity (ROE) tidak memiliki pengaruh signifikan terhadap variabel dependen Return Saham.Hasil penelitian ini sejalan dengan penelitian sebelumnya yang dilakukan oleh Mulyawan (2015) yaitu CR, DER,TATO, ROE secara simultan tidak berpengaruh signifikan terhadap return saham, namun bertentangan dengan penelitian yang dilakukan oleh Daljono dan Nugroho (2015) yaitu yaitu CR, DER,TATO, ROE secara simultan berpengaruh signifikan terhadap return saham.

Hasil koefisien regresi variabel current ratio tidak berpengaruh signifikan terhadap return saham pada sektor Otomotif dan Komponen Lainnya Pada Bursa Efek Indonesia Tahun 2012 samapai 2017. Hal ini karena CR yang tinggi tidak mempengaruhi minat investor dalam menanamkan modalnya, karena tingginya nilai CR menunjukan kemampuan perusahaan dalam mengelola aktiva lancar yang kurang baik, sehingga banyak aktiva lancar yang yang mengangur dan tidak dioptimalkan oleh perusahaan yang berakibat pada menurunnya minat investor dalam menanamkan modalnya. Minat investor yang menurun ini berakibat pada turunnya harga saham pada perusahaan sehingga mengakibatkan return saham perusahaan juga ikut menurun, tidak adanya pengaruh signifikan dari CR terhadap return saham mengandung arti bahwa CR yang besar pada perusahaan diinterprestasikan secara bervariasi oleh investor. Hasil penelitian ini sejalan dengan penelitian sebelumnya yang dilakukan oleh Wibowo (2015) yaitu Current Ratio (CR) tidak berpengaruh signifikan terhadap return saham, namun bertentangan dengan penelitian yang dilakukan oleh Safitri (2015) yaitu CR berpengaruh positif signifikan terhadap return saham.

Hasil koefisien regresi variabel Debt to Equity Ratio (DER) tidak berpengaruh signifikan terhadap return saham pada sektor Otomotif dan Komponen Lainnya Pada Bursa Efek Indonesia Tahun 2012 
sampai 2017, tidak adanya pengaruh signifikan terhadap return saham berarti bahwa ada penilaian yang berbeda dari investor arti pentingnya hutang dari perusahaan. Investor dapat berfikir bahwa DER yang besar akan menjadi beban bagi perusahaan karena adanya kewajiban perusahaan untuk membayar hutang dan adanya risiko kebangkrutan yang akan ditanggung oleh investor, disisi lain investor juga berpendapat bahwa hutang sangat dibutuhkaan oleh perusahaan karena dengan memiliki hutang yang besar dapat digunakan untuk meningkatkan modal perusahaan sehingga perusahaan dapat mengembangkan usahanya, dengan melakukan pengembangan usaha maka investor tertarik untuk membeli perusahaan tersebut sehingga harga saham perusahaan tersebut naik dan return saham juga naik.

Hasil koefisien regresi variabel Total Assets TurnOver tidak berpengaruh signifikan terhadap return saham pada sektor Otomotif dan Komponen Lainnya Pada Bursa Efek Indonesia Tahun 2012 samapai 2017. Hal ini bahwa kemampuan perusahaan untuk mengoptimalkan aktivanya secara efektif dan efisien ternyata tidak berpengaruh terhadap minat investor untuk membeli saham perusahaan tersebut, hal ini karena penurunan penjualan tdak diikuti dengan menurunnya total aset, dimana pada perusahaan otomotif penjualan setiap tahunnya mengalami kenaikan dan penurunan, sedangkan total aset setiap tahunnya terus mengalami kenaikan ini berakibat pada nilai TATO yang didapatkan oleh perusahaan, sehingga dengan tidak di ikutinya kenaikan penjualan membuat invetor tdak tertarik untuk menanamkan modal pada perusahaan tersebut yang akan berakibat pada menurunnya harga saham yang berakibat pada menurunnya return saham perusahaan.

Berdasarkan hasil pengujian analisis regresi linear berganda dengan bantuan SPSS 16 For Windows diperoeh hasil koefisien regresi variabel Total Assets TurnOver tidak berpengaruh signifikan terhadap return saham pada sektor Otomotif dan Komponen Lainnya Pada Bursa Efek Indonesia Tahun 2012 sampai 2017. Hal ini bahwa kemampuan perusahaan untuk mengoptimalkan aktivanya secara efektif dan efisien ternyata tidak berpengaruh terhadap minat investor untuk membeli saham perusahaan tersebut, hal ini karena penurunan penjualan tdak diikuti dengan menurunnya total aset, dimana pada perusahaan otomotif penjualan setiap tahunnya mengalami kenaikan dan penurunan, sedangkan total aset setiap tahunnya terus mengalami kenaikan ini berakibat pada nilai TATO yang didapatkan oleh perusahaan, sehingga dengan tidak di ikutinya kenaikan penjualan membuat invetor tdak tertarik untuk menanamkan modal pada perusahaan tersebut yang akan berakibat pada menurunnya harga saham yang berakibat pada menurunnya return saham perusahaan.

\section{KESIMPULAN DAN SARAN}

\section{Kesimpulan}

1. Berdasarkan hasil perhitungan variabel likuiditas (Current Ratio), solvabilitas (Debt to Equity Ratio), aktivitas (Total Assets TurnOver), dan profitabilitas (Return On Equity) secara simultan tidak berpengaruh signifikan terhadap return saham pada perusahaan Otomotif dan Komponen Lainnya Pada Bursa Efek Indonesia tahun 2012 sampai 2017.

2. Berdasarkan hasil perhitungan terbukti bahwa likuiditas (Current Ratio), secara parsial tidak berpengaruh signifikan terhadap return saham pada perusahaan Otomotif dan Komponen Lainnya Pada Bursa Efek Indonesia tahun 2012 sampai 2017.

3. Berdasarkan hasil perhitungan terbukti bahwa solvabilitas (Debt to Equity Ratio), secara parsial tidak berpengaruh signifikan terhadap return saham pada perusahaan Otomotif dan Komponen Lainnya Pada Bursa Efek Indonesia tahun 2012 sampai 2017.

4. Berdasarkan hasil perhitungan terbukti bahwa aktivitas (Total Assets TurnOver), secara parsial tidak berpengaruh signifikan terhadap return saham pada perusahaan Otomotif dan Komponen Lainnya Pada Bursa Efek Indonesia tahun 2012 sampai 2017. 
5. Berdasarkan hasil perhitungan terbukti bahwa profitabilitas (Return On Equity) secara parsial tidak berpengaruh signifikan terhadap return saham pada perusahaan Otomotif dan Komponen Lainnya Pada Bursa Efek Indonesia tahun 2012 sampai 2017.

\section{Saran}

1. Bagi manajemen perusahaan Otomotif dan Komponen Lainnya perlu memerhatikan likuiditas, solvabilitas, aktivitas dan profitabilitas. Dimana jika perusahaan meningkatkan rasio tersebut terutama profitabilitas maka akan meningkatkan modal yang dimiliki sehingga akan mempengaruhi return saham dipasar modal.

2. Bagi investor sebelum melakukan investasi dan pembelian saham pada suatu perusahaan Otomotif dan Komponen Lainnya sebaiknya, melihat pertumbuhan dan perkembangan suatu perusahaan baik dari segi kinerja keuangan maupun return saham yang dihasilkan perusahaan tersebut.

3. Bagi peneliti sebaiknya:

a. Peneliti berikutnya sebaiknya perlu melakukan analisis terhadap semua emiten yang terdaftar di Bursa Efek Indonesia agar dapat memberikan pandangan yang luas bagi investor yang ingin berinvestasi.

b. Peneliti berikutnya perlu menganalisis pengaruh kinerja keuangan lainnya dari lingkungan internak selain CR, DER, TATO, ROE seperti ROA, PBV, EPS lainnya yang belum dianalisis dalam penelitian ini berguna untuk mengetahui bagaimna pengaruhnya terhadap return saham.

c. Periode pengamatan pada penelitian selanjutnya sebaiknya diperpanjang agar diperoleh hasil penelitian yang lebih baik.

\section{REFERENSI}

Ambarwaty, Sri, Dwi, Ari, (2010) Manajemen Keuangan Lanjut, Graha Ilmu, Yogyakarta

Daljono, Nugroho dkk, (2013). Pengaruh Kinerja Keuangan Terhadap Retur di Bursa Efek Indonesia,

Vol.2. Fakultas Ekonomi dan Bisnis, Universitas Ponegoro, Semarang .

Darsono, (2007). Manajemen Keuangan, cetakan kedua, Diadit Media, Jakarta.

Fahmi, Irham, (2016). Pengantar Manajemen Keuangan (TeoridanSoalJawab), Alfabeta, Bandung.

Ghozali, Imam (2016) Aplikasi Analisis Multivariate dengan Program IBM SPSS 23. Semarang: Badan Penerbit Universitas Diponegoro.

Gozali, Imam, (2013).Aplikasi Analisis Multivariate dengan Program SPSS., Edisi ketujuh, Universitas diponegoro, Semarang.

Hartijo, Martono, (2012). Manajemen Keuangan, cetakan kedua, Ekonosia, Jogyakarta.

Jensen, Michael C, Dan Wiliam H. Meckling (1998). Theory Of The Firm:Manjerial Behavior, Agency Cost, And Ownership Structure. Journal Of Financial Economics, Vol 3, No 4, Pp.305-360

Kasmir, (2010). Pengantar Manajemen, Cetakan Pertama, Kencana Prenada Media Grup, Jakarta.

Kurniawan, Albert, (2014). Metode Riset Untuk Ekonomi dan Bisnis, ALFABETA, Bandung.

Mulyawan, Setia, (2015). ManajemenKeuangan, CV PustakaSetia, Bandung

Mulyawan, (2015). Analisis Pengaruh Rasio Keuanngan Terhadap Return Saham Pada Perusahaan

Manufaktur di Bursa Efek Indonesia (BEI). Jurnal Manajemen Dan Bisnis.Vol.6 No.1. Universitas Bandar Lampung.

Nurhikmah,Sitti, (2012). Pengaruh Kinerja Keuangan Terhadap Return Saham Studi Kasus Pada Industri Manufaktur yang Terdaftar di Bursa Efek Indonesia, Fakultas Ekonomi, Jurusan Manajemen, Universitas Hasanuddin. Makassar. 
Vol. 6, No.2, Mei 2020, 149-157

Rahcmawati, Rahayu, (2017). Pengaruh Kinerja Keuangan Terhadap Retrun Saham Perusahaan Manufaktur di Bursa Efek Indonesia, Vol.6, 2460-0585 Sekolah Tinggi Ilmu Ekonomi Indonesia (STIESIA), Surabaya.

Safitri, Ratih, Diyah, (2015). Pengaruh Kinerja Keuangan Perusahaan Terhadap ,Bursa EfekIndonesia, Fakultas Ekonomi, Universitas Negeri Semarang, Semarang.

Sugyono, 2014. Metode Penelitian Manajemen, ALFABETA, Bandung. 2015. Metode Penelitian Manajemen, ALFABETA, Bandung.

Syeh, Muhammad 2016 Analisis Faktor-faktor yang memepengaruhi Retrun Saham, jurusan akuntansi, fakultas ekonomi, universitas muhammadiyah, Surakarta.

Syuaib Dkk (2015). Pengaruh Rasio Profitabilitas Pada Industri Perbankan yang Go Public Terhadap Harga Saham di Bursa Efek Indonesia. Jurnal Ilmu Manajemen. Vol.1 No.1, ISSNONLINE 2443-3578, Universitas Tadulako.

Wibowo, Feri, Widi, 2015. Pengaruh Kinerja Keuangan Terhadap Retrun Saham Pada Perusahaan Manufaktur yang Terdaftar di Bursa Efek Indonesia, Fakultas Ekonomi, Jurusan Manajemen, Universitas Muhammadiyah. Surakarta.

http://www.idx.co.id

http://www.sahamok.com

http://www.finance.yahoo.com 